\title{
Gis 技术在贵州兴义地质遗迹资源调查中的应用
}

\section{Application of Gis Technology in the Investigation of Geological Heritage Resources in Xingyi City of Guizhou Province}

\author{
廖浚伶 ${ }^{1}$ 楼明君 ${ }^{2}$ 程溪 ${ }^{3}$ 郭䂞后 $^{1}$ \\ Junling Liao ${ }^{1}$ Mingjun Lou $^{2}$ Xi Cheng ${ }^{3}$ Lei Guo ${ }^{1}$ \\ 1. 兴义民族师范学院经济与管理学院 中国·贵州 兴义 $562400 ； 2$. 浙江省第三地质大队 中国·浙江 金华 321001 ; \\ 3 . 兴义民族师范学院教育科学学院 中国・贵州 兴义 562400 \\ 1. Colleges of Economics and Management, Xingyi Normal University for Nationalities, Xingyi, Guizhou, 562400, China; \\ 2. The Third Geological Brigade of Zhejiang Province, Jinhua, Zhejiang, 321001, China; \\ 3. Colleges of Educational Science, Xingyi Normal University for Nationalities, Xingyi, Guizhou, 562400, China
}

摘 要: 贵州兴义具有典型锥形喀斯特地貌景观和贵州龙动物群的珍贵资源。在贵州大力发展山地旅游和地质旅游背景下, 摸清地质遗迹资源家底至关重要。在此, 旨在使用 Gis 技术分析贵州兴义主要地质遗迹特征, 将其应用于贵州兴义旅游地质的 开发。

\begin{abstract}
Xingyi City of Guizhou Province has a typical cone-shaped karst landscape and the precious resources of Keichousaurus fauna. Under the background of Guizhou's vigorous development of mountain tourism and geotourism, it is very important to find out the status of geological heritage resources. In this paper, the purpose is to use Gis technology to analyze the characteristics of the main geological relics in Xingyi of Guizhou, and apply them to the development of tourism geology in Xingyi of Guizhou.
\end{abstract}

关键词: 旅游地质; 地质遗迹资源; Gis 技术; 锥状喀斯特; 贵州龙动物群

Keywords : tourism geology, geological heritage resources, Gis technical analysis, Cone karst, Keichousaurus Fauna

\section{DOI : 10.36012/etr.v2i8.2510}

\section{1 引言}

地质遗迹资源的定义存在争议, 有学者提出, 地质遗迹 资源是在漫长的地质时期，在各种地质作用下形成的不可 再生的珍贵地质自然遗产[1 3 3 。旅游地质属于地质科学应用 的范畴, 强调从地质的角度, 科普化的方法解释风景成因、 演变和影响 ${ }^{[4]}$ 。而贵州省作为世界上三个最密集的喀斯特区 域之一 ${ }^{[5]}$, 其碳酸盐岩裸露面积较广, 面积为 $130,000 \mathrm{~km}^{2}$, 占 贵州总面积的 $61.50 \%$ 。所以, 贵州地质遗迹具有种类多、 品位高的特点, 有丰富的旅游资源 ${ }^{[6]}$ 。此外, 贵州省还获有 古生物王国之称, 在兴义、关岭、盘县、瓮安埋藏有重要古生 物群 ${ }^{[7]}$ 。

贵州省的兴义地区更是全方位、多层次地集中展现了喀 斯特回春发育的一个完整景观系列[8]。而兴义动物群作为晚
三叠世界海生爬行动物群的代表, 囊括各种海生爬行动物和 鱼虾 ${ }^{[1]}$ 。另一方面, 近年来, 贵州省获批 8 家国家地质公园 ${ }^{[1]}$ 。 在 2017 年, 兴义国家地质公园开始世界地质公园的拟建。在 这种背景下兴义民办博物馆应运而生。在贵州省全面决战脱 贫攻坚之时, 民办博物馆的合理开发可以带动地方农村经济 的发展, 有利解决部分农村人口的就业问题。贵州兴义的地 质遗迹资源丰富、情况复杂, 传统的技术已不能很好地满足 调查需求。遥感影像中多波段信息能很好地直观反映地貌景 观, 可用于解译喀斯特地貌的区域上差异。在此, 以 Gis 技术 进行贵州兴义地质遗迹资源的调查为例进行分析, 对贵州兴 义喀斯特地貌区域与非喀斯特地貌区域在岩性和水文构造 的差异进行对比, 以期实现旅游地质的科普性, 在保护之下 求发展 ${ }^{[0,11]}$ 。

【基金项目】地质旅游背景下民间博物馆的科普研究, 20180XN79628。 


\section{2 研究对象}

\section{1 研究区概况}

兴义市地处贵州省黔西南地区, 位置的经纬度为 $104^{\circ}$ $32^{\prime}-105^{\circ} 11^{\prime}$, 北纬 $24^{\circ} 38^{\prime}-25^{\circ} 23^{\prime}$ 。兴义的地质构造属于黔 西南普安的旋扭构造变形, 据统计, 区内计 11 个断层, 7 个褶 皱带。上新世新构造运动的大幅度抬升的影响, 最终造就兴 义由西北向东南逐级降低的多级台面, 地貌就表现为西高东 低的特征。兴义境内地表迳流以及地下迳流充沛, 水文地质 构造上为碎屑岩和碳酸盐岩组成的二元水文地质结构 ${ }^{[12]}$ 。地 形上, 兴义的高程变化大, 范围为 625 2207.7m( 见图 1), 综 合因素影响下造成了兴义地形地貌复杂。岩性上, 兴义出露 的地层以三叠系分布最为广泛, 约占全区总共面积的 $90 \%$ 。 也就是在晚三叠世的地层中发现大量以贵州龙为主体的兴 义动物群化石 ${ }^{[13]}$ 。

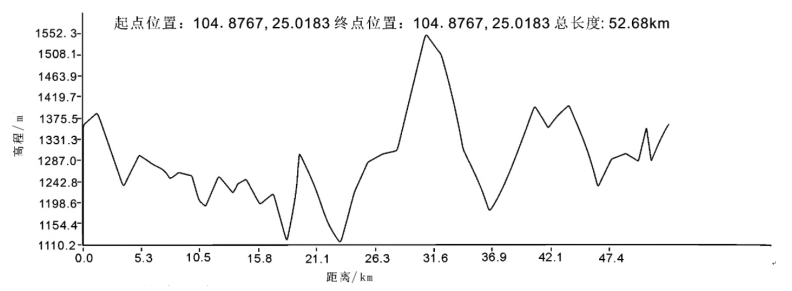

图 1 兴义的海拔高程变化图

\section{2 兴义的典型地质遗迹资源概况}

兴义的地质遗迹喀斯特景观有峰林、石林、峡谷、溶洞、 漏斗、天坑等。按照喀斯特类型兴义景区有边坡角度在 $45^{\circ}$ 左 右的锥状喀斯特景观类型、形态较笔直的针状喀斯特景观类 型; 边坡角度 $>45^{\circ}$, 底部略宽缓的塔状喀斯特景观类型 ${ }^{[14]}$; 以 及边坡角度约 $90^{\circ}$ 的针状喀斯特景观类型(见图 2)。而在戴 维斯演化理论中, 锥状喀斯特景观代表着喀斯特地貌发育的 青壮年期; 塔状喀斯特景观代表了发育到了老年期。另一方 面, 兴义化石资源丰富, 分别有 12 个古生物群化石产地: 顶 效后龙山化石产地、光堡堡山化石点、猴子菁化石点、谢米化 石点、革里化石点、酒布化石点、革居化石点、干石洞化石点、 佳克化石点、永康桥化石点、新发化石点、罗家湾化石点。多 年来, 共发现有三叠纪海生脊椎动物 27 属 30 种, 分别有贵 州龙、蛇颈龙、鱼龙、海龙、幻龙、欧龙、飞鱼、小鳞贵州鲟、小 短体鱼、秀丽兴义鱼、弓鰙鱼、中华真领鱼, 龙鱼等 ${ }^{[15]}$ 。

\section{3 研究方法和数据来源}

通过实地勘探的方式对兴义的地质遗迹资源摸底调查, 运用 Gis 信息技术对地貌景观进行遥感解译。使用 Lansat Capernicus 最新的影像数据, 结合多年的实地勘探数据资料,

\begin{tabular}{|c|c|c|c|}
\hline \multirow[b]{2}{*}{ 景区 } & \multirow{2}{*}{$\begin{array}{l}\text { 喀斯特 } \\
\text { 类 型 }\end{array}$} & \multicolumn{2}{|c|}{ 地貌景观 } \\
\hline & & 地表喀斯特 & 地下喀斯特 \\
\hline 北峰林 & \multirow{2}{*}{ 雉状喀斯特 } & \multirow{2}{*}{ 峰丛 } & 洼地、漏斗 \\
\hline 南峰林 & & & 溶洞/落水洞/天坑 \\
\hline 东峰林 & \multirow{2}{*}{ 塔状喀斯特 } & \multirow{2}{*}{ 峰林盆地 } & \multirow[b]{2}{*}{ 漏斗/溶洞/落水洞 } \\
\hline 西峰林 & & & \\
\hline $\begin{array}{l}\text { 白马地石林、 } \\
\text { 风波湾石林、 } \\
\text { 戴家坝石林 }\end{array}$ & 针状喀斯特 & 石林 & 溶洞 \\
\hline
\end{tabular}

图 2 兴义典型喀斯特类型

对兴义地质遗迹资源进行分析。在遥感影像上摸清地质遗迹 资源家底的基础上,丰富旅游资源数据库。

\section{3 兴义地质遗迹资源的遥感影像分析}

通过对兴义地噃遥感图的解译发现, 兴义的喀斯特地 貌分布呈现这样的规律: 兴义喀斯特地貌在遥感影像中呈 封闭的蜂窝状结构。山峰在遥感图上的形状体现了新构造 运动后的地质作用对地貌的强烈切割[16]。非喀斯特区域 (敬 南以南)显得宽平。整体上, 兴义喀斯特集中分布区呈现深 绿色, 北南向的兴义喀斯特地貌形状为帚状, 东西向的喀斯 特地貌形状为带状。其中, 敬南主要分布的是峰丛深洼, 在 遥感影像中来看, 相较顶效的峰林平原更加深凹。对比下, 非喀斯特区域在影像中颜色较浅（如顶效以北以及泥水以 南), 呈较浅的灰色。

岩性上, 研究区的典型喀斯特地貌均发育在垄头组 ( T2l) 和杨柳井组加垄头组 $(\mathrm{T} 2 \mathrm{y}+\mathrm{T} 2 \mathrm{l})$ 的地层分布区, 其中兴 义以南敬南一纳灰一带的西峰林与泥水石林区发育在垄头 组 ( T2l); 顶效以南的东峰林和南峰林虽发育在垄头组 ( T2l) 的地层分布区。西峰林和东峰林以北的地区主要出露杨柳井 组地层, 为一套泥质夹层多的白云岩, 生成的为圆滑的小丘, 喀斯特地貌并不典型。敬南以南地区在三叠纪早期为深海盆 地, 主要出露的是边阳组的碎屑岩, 喀斯特地貌不在那发育。 在遥感影像中, 地貌上的区别实际上是岩性不同的表现, 在 敬南以南为界线呈现了明显的区别。水文地质结构上, 遥感 图上南盘江水系纵横, 由于边阳组碎屑岩的阻隔, 敬南以北 区域外源水的集中,造成侧向溶蚀为主的侵蚀作用,而来自 碎屑岩的地表水与地下水化学侵蚀性极强, 造成贵州兴义连 片的喀斯特地貌景观（见图 3 )。

\section{4 运用 Gis 技术合理规划发展路线}

与此同时, 兴义的化石之家在贵州龙首次发现地顶效镇 绿萌村以及乌沙镇泥麦古村化石发掘地。而在兴义进入申报 


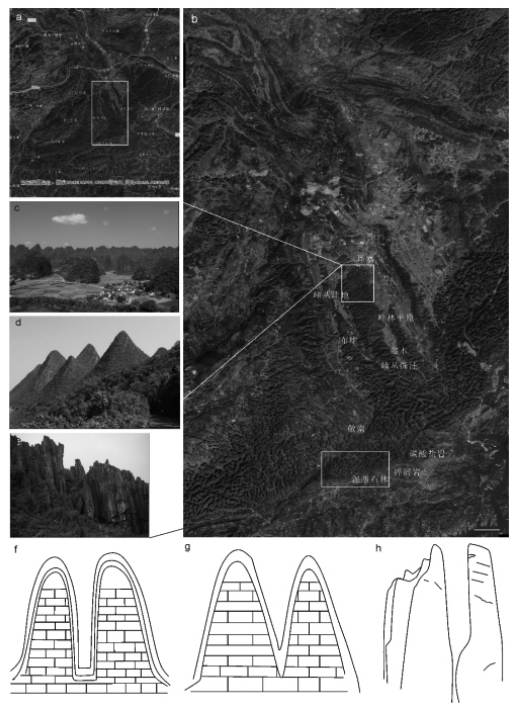

$\mathrm{a}$ 一兴义区域卫星图图,比例尺: $5 \mathrm{~km} ; \mathrm{b}-\mathrm{a}$ 图的放大图, 影像级数:

13 级, 分辨率为 17.34 /像素, 比例尺: $10 \mathrm{~km}$; $\mathrm{c}$ 一峰林盆地 (塔状喀斯 特类型代表); $\mathrm{d}$ 一峰丛洼地 (雉状喀斯特类型代表); $\mathrm{e}$ 一石林 (针状 喀斯特代表); $\mathrm{f}$ 一塔状喀斯特类型线形图; $\mathrm{g}$ 一雉状喀斯特类型线形

\section{图; h一雉状喀斯特类型线形图}

\section{图 3 兴义地貌类型}

世界地质公园的名单中,民办博物馆的建立势在必行。但是, 中国民办博物馆仅占博物馆总数的 $5 \%$, 票价难以承担成本。 所以,如何创办并运行民办博物馆是关键性问题。应以顶效 和乌沙为基点, 进行实地勘探, 运用 Gis 技术进行矢量化分 析,设立一个科学的科考路线。还可以采用三维激光扫描技 术获取信息,进行资源信息进行存储 ${ }^{[17]}$ 。以喀斯特地貌成因 为例, 可以用遥感影像结合三叠纪时期的兴义古地理情况还 原贵州龙生物群的生活环境、化石的 3D 修复 ${ }^{[18]}$ 为内容, 开展 旅游地质的科普工作。还可以使用数据化模型直观反映喀斯 特地貌的演化和化石形成, 寓教于娱乐 ${ }^{[19]}$ 。

此外,将 Gis 技术应用于摸清其他资源信息, 建立其他 资源为辅的科学产业链, 可以实现以馆养馆。毕竟, 贵州兴义 的农村资源也极为丰富的, 其中贵州兴义的中药资源尤为丰 富, 近 2000 种 ${ }^{[20]}$ 。应对贵州兴义药物资源所在地的经纬度和 高程进行实地勘探了解, 就可以进入 Gis 系统分析所在地岩 性、水文、地形、地质构造的情况, 从而实现科学发展。

\section{参考文献}

[1] 杨涛,戴塔根,武国辉. 地质遗迹资源的概念 [J].中国国土资源经 济,2007(12):25-27.

[2] 杨涛, 武国辉, 陈珊. 论地质遗迹资源价值管理[J]. 矿物学报, 2007,27(3):524-529.
[3] 冯天驱.中国地质旅游资源[M]. 北京:地质出版社,1998.

[4] 殷维翰. 为搞好旅游地质工作而努力[J]. 地质通报,1987(1):316.

[5] Zhou, Z. F, Zhang, S. Y; Xiong, K.N., et al. The spatial distribution and factors affecting karst cave development in Guizhou Province [J]. Journal of Geographical Sciences, 2017,27(8):1011-1024.

[6] 孙亚莉. 贵州地质公园地质遗迹资源特点及其保护建议[J]. 贵州 地质,2006(2):40-45.

[7] 赵元龙.古生物王国[M].贵州:贵州科技出版社,2002.

[8] 徐柯健,李兴中,刘嘉麒.贵州兴义喀斯特景观特征[J].中国岩溶, 2008(2):63-70.

[9] 李丙霞,喻美艺. 论贵州省地质公园的建设和发展 [J]. 上海国土 资源,2011(1):76-79.

[10] Wei, Q. W. Community Archaeology and Alternative Interpretation of the Past through Private Museums in Shanghai, China [J]. Archaeologies, 2015,11(2):205-219.

[11] Wei, Q, Shi, F. State Archaeology and the Private Museum: An Integrated Approach to Archaeological Site Management for Local People in China [J]. Conservation Management of Archaeological Sites, 2016,18 (4):464476.

[12] 廖浚伶.泥水石林成因分析[J].现代农业科技,2012(9):325326 .

[13] 王立亭.贵州三叠纪海生爬行动物研究进展[J].贵州地质,2002 (1):7-10.

[14] 张英骏, 杨明德. 关于岩溶地貌类型划分与制图的某些问题(以 编制中国 1:100 万地貌图为例)[J].贵州师范大学学报,1983(1): 3-8.

[15] 刘冠邦,尹恭正,王雪华,等.贵州兴义晚三叠世贵州龙层新发现 的鱼类[J].古生物学报, 2003,42(3):346-366.

[16] 黄宝华, 郭福生, 姜勇彪, 等. 广丰盆地丹霞地貌遥感影像特征 [J].山地学报,2010,28(4):500-504.

[17] 张国超.我国民办博物馆的发展现状、问题与对策[J].江西社会 科学,2011(4):12-19.

[18] 石梅.杨文. 宁波民办博物馆的数字化推广研究[J].数字技术与 应用,2014(11):65,67.

[19] 陶思宇, 张喜光.3D 复原应用于古生物学的初探[J]. 古生物学 报,2010(3):149-160.

[20] 刘思昭,程晓冬,黄文娟.浅谈古生物化石数字模型在博物馆的 开发与应用.自然科学博物馆研究,2016(2):3-7. 